\title{
La ecografía debería ser el primer estudio por imágenes a realizar en pacientes con sospecha de nefrolitiasis
}

Ultrasound should be the first imaging study for a patient with suspected nephrolithiasis

\section{Objetivos}

Determinar si la Ecografía o la Tomografía Computada es el método por imágenes apropiado en la evaluación inicial del paciente con sospecha de nefrolitiasis.

\section{Diseño}

Ensayo clínico pragmático, aleatorizado, y multicéntrico que se llevó a cabo entre el 2011 y 2013 en 15 centros de Estados Unidos.

\section{Pacientes}

Se reclutaron 2759 pacientes, de 18 a 76 años de edad, que concurrieron al departamento de emergencias por dolor en el abdomen o flanco y en quienes el médico tratante establece la posibilidad de nefrolitiasis como causal. Se excluyeron a los pacientes considerados de alto riesgo de presentar un diagnóstico alternativo serio (ej. colecistitis, apendicitis, aneurisma aórtico o trastornos intestinales), pacientes monorrenos, con insuficiencia renal o trasplantados renales, embarazadas, y a mujeres y hombres con peso mayor a 113 y $129 \mathrm{~kg}$, respectivamente.

\section{Intervenciones}

Los pacientes fueron aleatorizados a alguna de las siguientes estrategias iniciales de diagnóstico por imágenes: Ecografía realizada por un médico emergentólogo, Ecografía realizada por un radiólogo, o Tomografía Computada. Tanto los pacientes como los profesionales fueron conscientes de la intervención realizada.

\section{Medición de resultados principales}

Se definieron como resultados principales a la ocurrencia de diagnósticos de alto riesgo que no se hubiesen diagnosticado a partir del estudio índice y a la magnitud de exposición a radiación ionizante (acumulada a los seis meses de la aleatorización). Los diagnósticos de alto riesgo fueron pre-especificados y definidos como aquellos diagnosticados dentro de los 30 días de la visita ini-
Smith-Bindman R y col. NEJM. 2014;371:1100-10. cial. Entre ellos se incluyeron a la ruptura de aneurisma abdominal, neumonía con sepsis, isquemia o perforación intestinal, infarto renal, pielonefritis con urosepsis, torsión ovárica con necrosis, y disección aórtica con isquemia.

Los resultados secundarios comprendieron los efectos adversos severos, la reconsulta en el central de emergencia, dolor autorreportado, y precisión diagnóstica (sensibilidad y especificidad). Para recabar estos, los pacientes fueron contactados y encuestados en varias instancias y hasta los 180 días posteriores a la intervención. Los análisis fueron por intención de tratar excepto para calcular la precisión diagnóstica, que se limitó al análisis del primer estudio realizado.

\section{Resultados principales}

Los resultados principales se resumen en la tabla 1.

No hubo diferencias significativas en los diagnósticos de alto riesgo, la frecuencia de efectos adversos posteriores, la cantidad de reconsultas e internaciones, el grado de dolor reportado, así como tampoco en la cantidad de pacientes a quienes se le confirmó nefrolitiasis dentro de los seis meses posteriores. Por el contrario, si se encontraron diferencias en la exposición acumulada a los rayos ionizantes, siendo significativamente mayor en el grupo inicialmente asignado a tomografía computada.

En relación a los costos, si bien un $40,7 \%$ de los pacientes en el grupo Ecografía por emergentólogo y un $27 \%$ de los pacientes del grupo Ecografía por radiólogo se realizaron una Tomografía Computada posterior, los costos del cuidado en emergencia fueron ligeramente menor en el grupo Ecografía.

Se perdieron del seguimiento un total de 113 pacientes, distribuidos de manera balanceada entre los grupos.

Tabla 1. Resultados primarios y precisión diagnóstica

\begin{tabular}{|c|c|c|c|c|c|}
\hline & $\begin{array}{c}\text { Ecografía por } \\
\text { emergentólogo }(n=908)\end{array}$ & $\begin{array}{l}\text { Ecografía por radiólogo } \\
\qquad(n=893)\end{array}$ & $\begin{array}{c}\text { Tomografía computada } \\
(n=958)\end{array}$ & $\begin{array}{c}\text { Diferencia entre grupos } \\
\text { Valor de p }\end{array}$ \\
\hline \multicolumn{2}{|c|}{ Diagnósticos de alto riesgo - Nro. de pacientes (\%) } & $6(0,7)$ & $3(0,3)$ & $2(0,2)$ & 0,30 \\
\hline \multicolumn{2}{|c|}{ Exposición a la radiación ionizante - $\mathrm{mSv} \pm \mathrm{DE}$} & $10,1 \pm 14,1$ & $9,3 \pm 13,4$ & $17,2 \pm 13,4$ & $<0,001$ \\
\hline Precisión diagnóstica & Sensibilidad \% (IC 95\%) & $54(48$ a 60$)$ & 57 (51 a 64) & 88 (84 a 92) & $<0,001$ \\
\hline para nefrolitiasis & Especificidad \% (IC 95\%) & $71(67$ a 75$)$ & $73(69$ a 77$)$ & 58 (55 a 62) & $<0,001$ \\
\hline
\end{tabular}

DE: desvío estándar.

\section{Conclusiones}

La Ecografía inicial estuvo asociada a una menor exposición acumulada a la radiación que la Tomografía Computada, sin presentar diferencias en los resultados diagnósticos de alto riesgo, efectos adversos, dolor, reconsultas, u hospitalizaciones.

Fuente de financiamiento: Agency for Healthcare Research and Quality.

\section{Comentario}

En concordancia con lo concluido en el artículo revisado, considero que la Ecografía debe ser la primera modalidad diagnóstica a solicitar en un paciente en quien se sospecha nefrolitiasis debido a su adecuada precisión diagnóstica, mayor disponibilidad, y ausencia de exposición a las radiaciones ionizantes.
Sin embargo, en aquellos pacientes en quienes el diagnóstico no es concluyente o se requiere de información adicional para decidir la conducta terapéutica, y en los centros donde está disponible, la Tomografía Computada debe realizarse adicionalmente ${ }^{1}$.

Pamela Ines Causa Andrieu [ Servicio de Diagnóstico por Imágenes del Hospital Italiano de Buenos Aires. pamela.causa@hospitalitaliano.org.armailto:pamela.causa@hospitalitaliano.org.ar mailto:pamela.causa@ hospitalitaliano.org.ar ]

Causa Andrieu PI. La ecografía debería ser el primer estudio por imágenes a realizar en pacientes con sospecha de nefrolitiasis. Evid Act Pract Ambul. 2016 ;19(3)86. Comentado de: Smith-Bindman R, y col. Ultrasonography versus computed tomography for suspected nephrolithiasis. NEJM. 2014;371(12):1100-10. PMID: 25229916. 